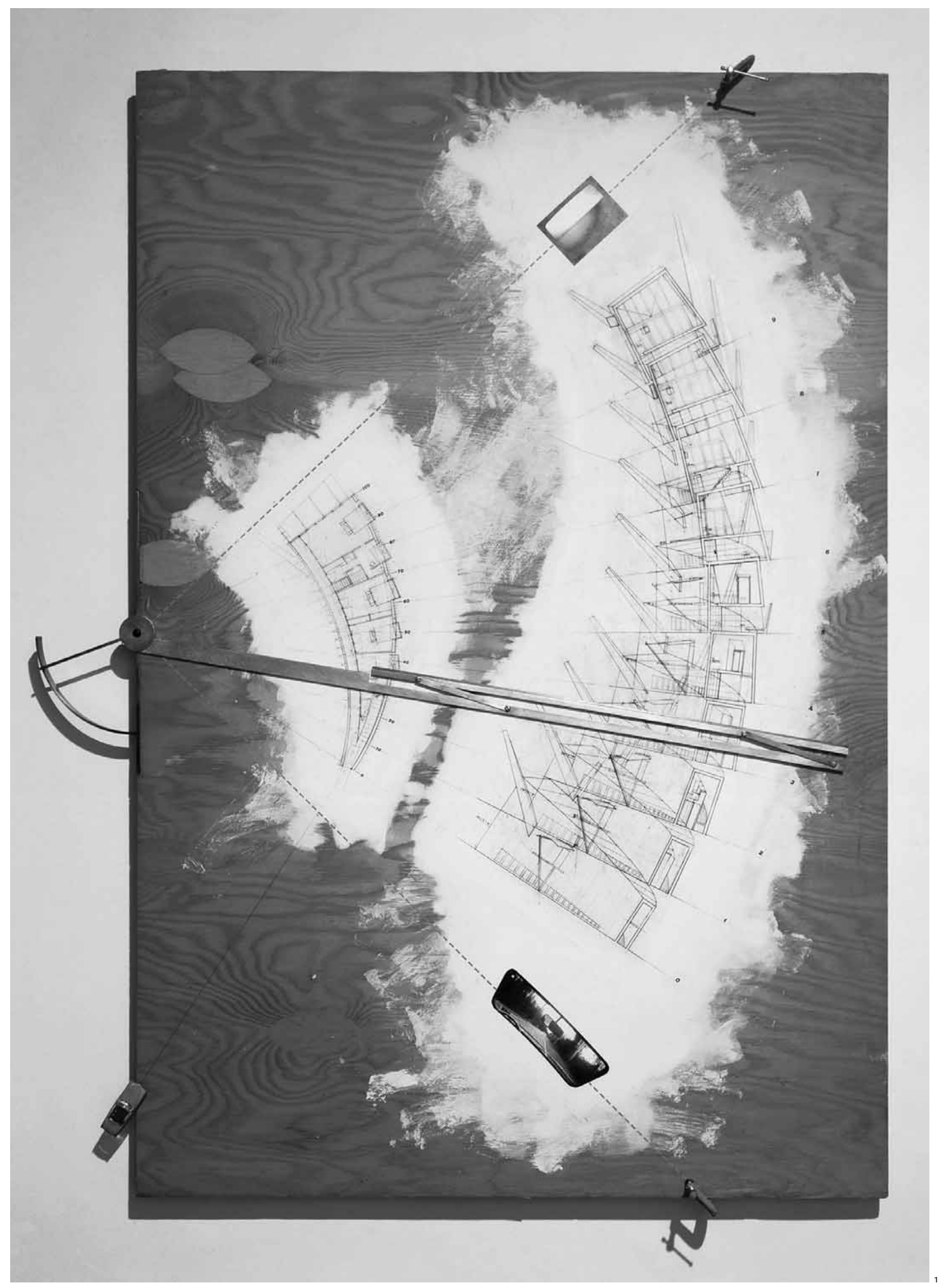




\title{
Three's a crowd: drawing, building and photography in the recent work of Diller Scofidio + Renfro
}

\author{
Christopher Pierce
}

\begin{abstract}
This is a short tale of two competing institutions and two of their most celebrated figures. On one side is Cooper Union - that hulking Manhattan brownstone, an island on the intersection of Lafayette Street and the Bowery where Ricardo Scofidio (1935) silently honed his art of drawing like an angel. On the other is Princeton University, where his partner (and partner), Elizabeth Diller (1954) is often resident. Princeton sits in the heart of the New Jersey woods, literally and metaphorically, and despite its baronial coniferous presence, is most notable in architectural circles for its rhetorical rather than physical manufacture. Diller + Scofidio's is a marriage whose vicissitudes are etched all over their work.

Their partnership is product of a classic tutor/student liaison and it is also one which the utterly ageless Scofidio - as old as the other great old men of Cooper Union including John Hejduk (1929-2000), Peter Eisenman (1932-), Raimund Abraham (1933-) and Lebbeus Woods (1940-) dominated in the ' 8 os and ' 90 s. Diller + Scofidio formed their collaborative partnership in 1979 but only built their first building in 2000 when their twosome was on the brink of becoming a threesome (with the promotion, to the level of partner as much as brand, of Charles Renfro). Even as legendary as Scofidio's drawings and some of Diller's early lectures is their name $-\mathrm{D}+\mathrm{S}$. The 'plus' sign was just so much cooler than the ampersand. They were the first to do it. We all know that the resonances of its studio chic filtered through to countless corporate practices after a little cache. It has since been adopted by everyone from Foster + Partners down.

One should then consider the plight of their three acolytes - Charles Renfro, Mark Wasiuta and Deane Simpson. For nearly a decade this coterie of boys filled Diller + Scofidio's love-shack-cum-office in the Village Voice building on Cooper Square. Given its proximity to Cooper Union and the debauched vibrancy of the Bowery it is not surprising that their architectural output is chiefly about transparency, occasionally opacity, and the theatre. One of these three diehards struck gold when it was announced in 2004 that Renfro had joined the lead pack. Only in
\end{abstract}

\begin{abstract}
the process that infamous acronym became DS+R. Now it is more like going to see your lawyer than your architect. Architectural troikas always seem to be about lawyers. There is Kohn Pedersen Fox (KPF), Skidmore, Owings \& Merrill (som) and Hellmuth Obata \& Kassabaum (нок). That sets the scene and the cast, except for one late arrival. Their most recent entrée is another über-cool boy, the Dutch architectural photographer Iwan Baan. In this tale Baan, like Scofidio, is not a rhetorician but an artisan. His polysemic shots are constructively questioning DS+R while (re)defining and enlarging, and at the same time rescuing their estranged architectural output.
\end{abstract}

\footnotetext{
Apparatus Drawing

In the late 1980 s, Diller + Scofidio produced a set of widely published drawings and models for a project that only ever got about 'six feet out from under', otherwise known by its apropos name - Slow House. To an impressionable architecture student, the jumble sale-like characteristics of the works and all of the references to the French pissoir-artist Marcel Duchamp (1887-1968) intrigued, aroused and admittedly even inspired me. It was the montage and projective geometry striptease that caught my eye. And the fact that, somehow, all those delicate little construction lines in the Apparatus Drawing [1] and protractor and compass-based crop circle-like figures in the Flayed Model [2] piloted this project to priestly realms. The building is tethered to gypsum board, plywood or a sheet of paper in a way that simultaneously recalls Gulliver's reckless plight and cartography's indefatigable determinism. Added to that, each of the drawings is labelled as though it is an artistic edifice. Their caption is their materiality.

At the same time, in the Apparatus Drawing, Diller + Scofidio implied that the source for these lines was something as prosaic as the shaft of a windshield wiper, with the building's plan the profane residue of a wipe in the plate glass. Apparently the building drew itself. That really would be Scofidio's ultimate trick. However much Diller's international lecture tour implicated Duchamp's more opaque works, you cannot help but sense the ready-made aspect of these
}

1 Apparatus Drawing, Diller + Scofidio 


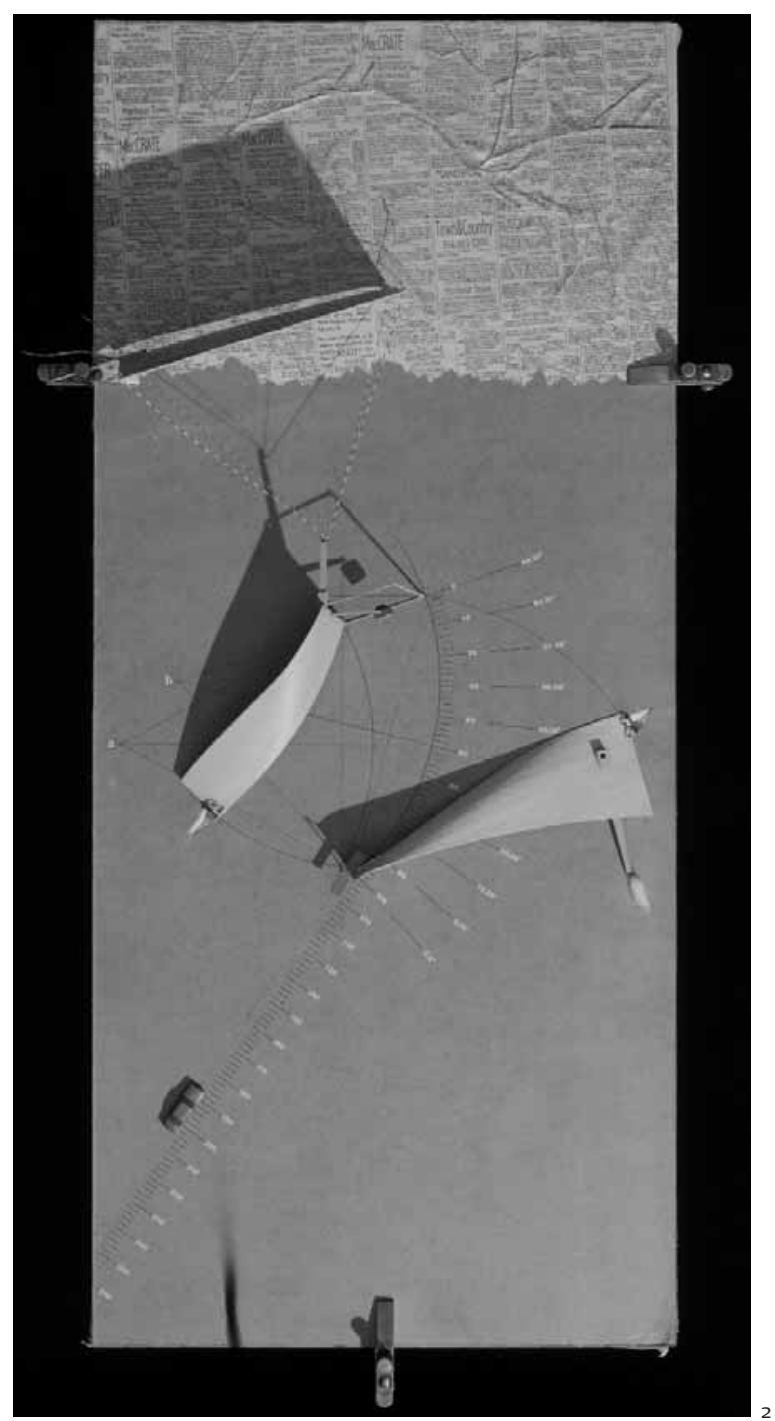

constructions. ${ }^{1}$ I was certainly not the only one who bought in to this versatile double act. So did Terence Riley, then Chief Curator of Architecture and Design at the Museum of Modern Art (MOMA). Both drawings, emerging from the kicked-about draughting tables and cutting mats of the Village Voice building, now reside uptown in climatically controlled white-gloved splendour as stalwarts of MoMA's collection. All that plywood, newspaper, messy paint and graphics - so much more New York than the pseudo-psychological drawings of their West Coast contemporaries, Thom Mayne and Michael Rotondi of Morphosis who formed in 1972 and realised their first building in 1974 - made for a heady entrée into architecture on the East Coast of the United States in the early 1990s. There might have been an inexplicable retro-mysticism to the origin of the Slow House but it was nothing compared to Mayne and Rotondi's self-referential designs in now equally as infamous drawings for projects in Southern California, including Lawrence House (1981) and 6th Street (1988) [3, 4], both of which, incidentally, were built.

$\begin{array}{ll}2 \begin{array}{l}\text { Flayed Model, Diller } \\ \text { +Scofidio }\end{array} & \begin{array}{l}\text { Water Bar } \\ \text { perspective, Blur } \\ \text { Building, Yverdon- }\end{array} \\ 3 \text { Lawrence House, } & \begin{array}{l}\text { les-Bains, } \\ \text { Switzerland, Diller + } \\ \text { Sermosa Beach, } \\ \text { California, } \\ \text { Morphosis }\end{array} \\ 4 \text { Isometrics and Plan, } \\ \text { 6th Street House, } \\ \text { Santa Monica, } \\ \text { California, } \\ \text { Morphosis }\end{array}$
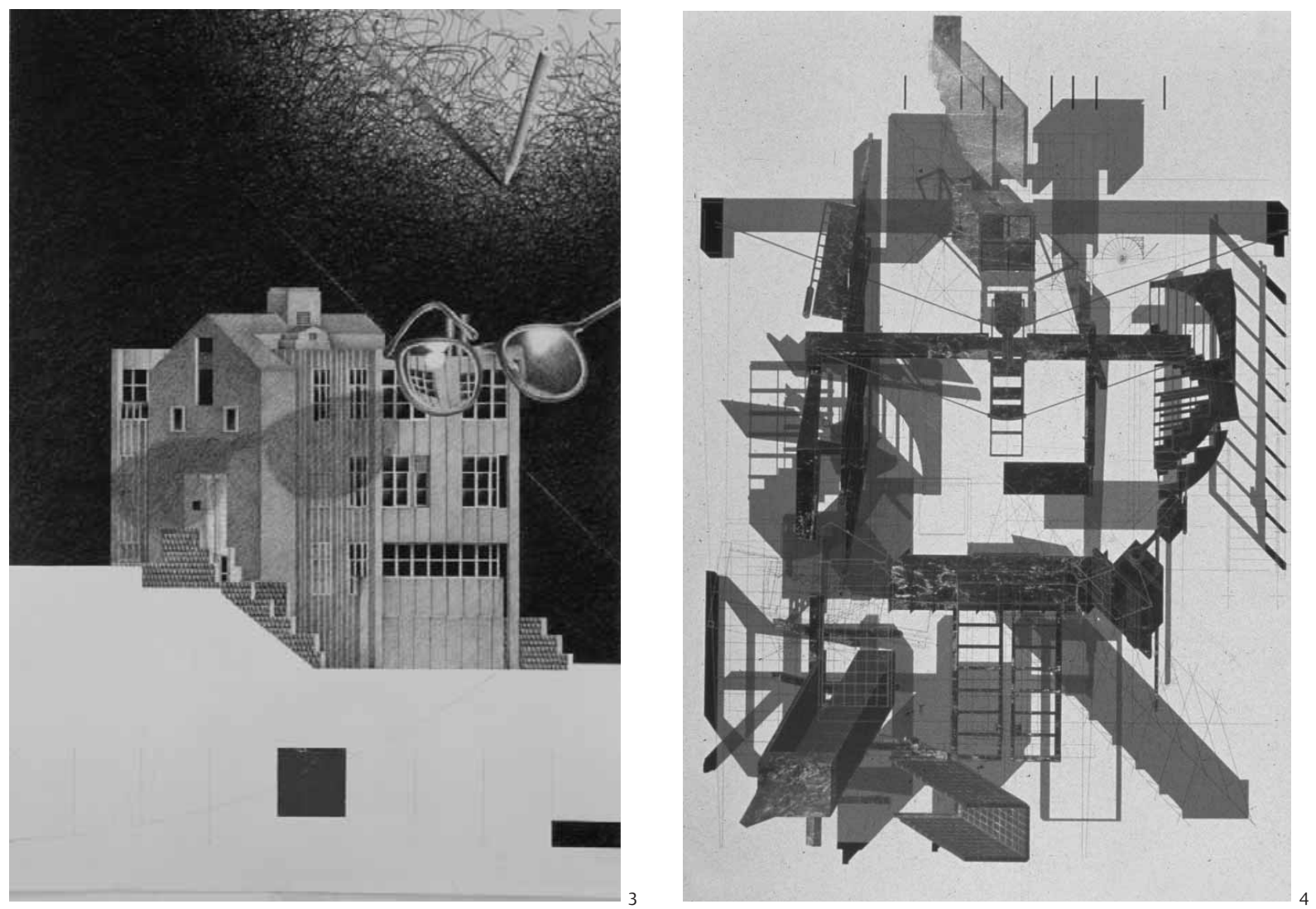


\section{The courage of one's commissions}

More than 10 years later, I wrote a short review on Diller + Scofidio's second volume of 'collected works'. ${ }^{2}$ Though they would never call it that. There are of course architects who unashamedly do, such as Norman Foster who has produced not one but two whole series of collected works. There are also those who do not and try to disguise it: aside from Diller + Scofidio, Rem Koolhaas and Peter Eisenman spring to mind. The collected works which isn't is titled Scanning: The Aberrant Architectures of Diller + Scofidio (2003). ${ }^{3}$ It has the requisite avant-garde title, Bret Easton Ellis-inspired cover and perforated pages. However, for all the modish Damian Hirst-like pharmaceutical references that it includes, over a decade later I was still struck by their drawings. The suitably provocatively titled slither Building and Blur Building being two significant actual additions to their previously virtual repertoire in the seven years since Georges Teyssot wrote them into the architectural avant-garde in his essay 'The Mutant Body of Architecture' in Flesh: Architectural Probes (1994). ${ }^{4}$ If ever there was an indication of a changing marriage, it has to be in their conversion from Flesh's tits and asses to Scanning's cocktail glasses. In Scanning it is clear that there is a demarcation in the presentation of Diller + Scofidio's architecture on either side of the 2002 Blur Building, nearly concomitant with Renfro's promotion.

The Blur Building is unquestionably Scofidio's greatest triumph. It is the pair's most resolute work, though its elegiac aspects cannot be missed. On one hand, the finished building was more drawing-like than any of their drawings and, on the other, it is the first time that they rendered an interior [5]. How ironic that the dust-free modern laboratory space in the water bar montage is populated by Photoshopped office staff languishing in Heath Robinson's attic off the gin-soaked Bowery.

Even though it was completed as recently as 200o, the Slither Building still seems like an extraordinary accident in the office's trajectory. Drawings of the aborted Slow House, late-199os favourites of the Slither Building like the Slither Flute Case Model [6] and rarer views including two 1930 sermaninspired drawings $[7,8]$, all resisted Adobe's overtures in favour of promoting a literary-philosophical know-how to the architectural intelligentsia. These finally gave way to a couple of trademark Pantone colours (patented shades of blue and green), crop shots and a few leftover pencil lines; techniques reaching their apotheosis at the unrealised Eyebeam Museum of New Media (2001). A similar Pantone fate ultimately befell Morphosis - in a set of shades of green, orange and yellow; colours that now dominate their super-slick digital images and that are, unlike Diller + Scofidio's, an integral part of the practice.

At the time of their 2003 retrospective at the Whitney Museum of American Art, Diller + Scofidio clung to the image of a couple of well-endowed bohemians whiling-away time in their increasingly ramshackle Cooper Square studio with their $\mathrm{HB}$ pencils. Only now they had all the accoutrements of the Swiss pharmacy to go with the antics of the Bowery bordello. However, the gypsum board robotic drilling (Mural, 2003) and toy robots encased in a Miesian box (Master Slave, 1999) that dominated the exhibition signalled the ascent of the pair from their opaque period in the twentieth century into the

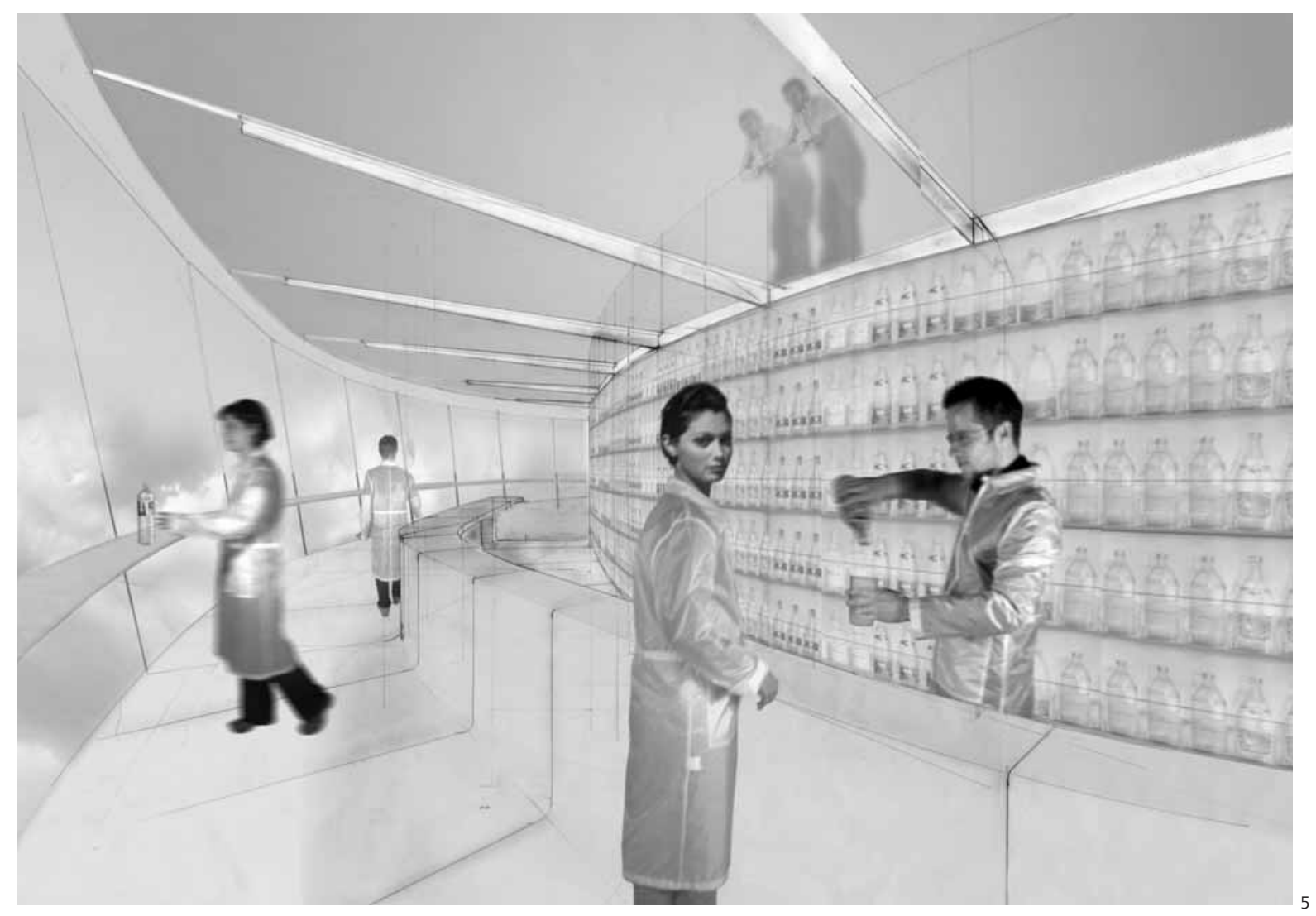




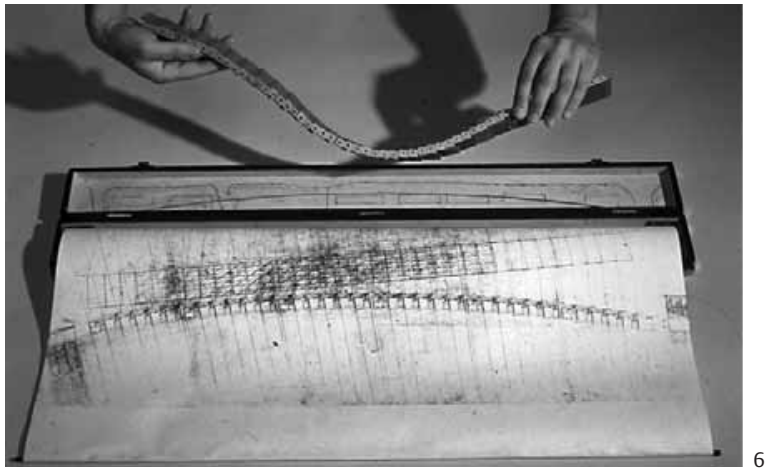

$\begin{array}{lr}6 \begin{array}{l}\text { Slither Flute Case } \\ \text { Model, Diller + } \\ \text { Scofidio }\end{array} & \begin{array}{r}\text { Slither Building, } \\ \text { Michael Moran }\end{array} \\ 7 \text { Slither Building, } & \begin{array}{r}\text { Section viewing } \\ \text { north, School of }\end{array} \\ \text { Gifu, Japan, Diller + } & \begin{array}{l}\text { American Ballet, } \\ \text { New York, Diller }\end{array} \\ \text { Scofidio } & \text { Scofidio + Renfro } \\ 8 \text { Slither Building, } & \\ \text { Diller + Scofidio } & \end{array}$
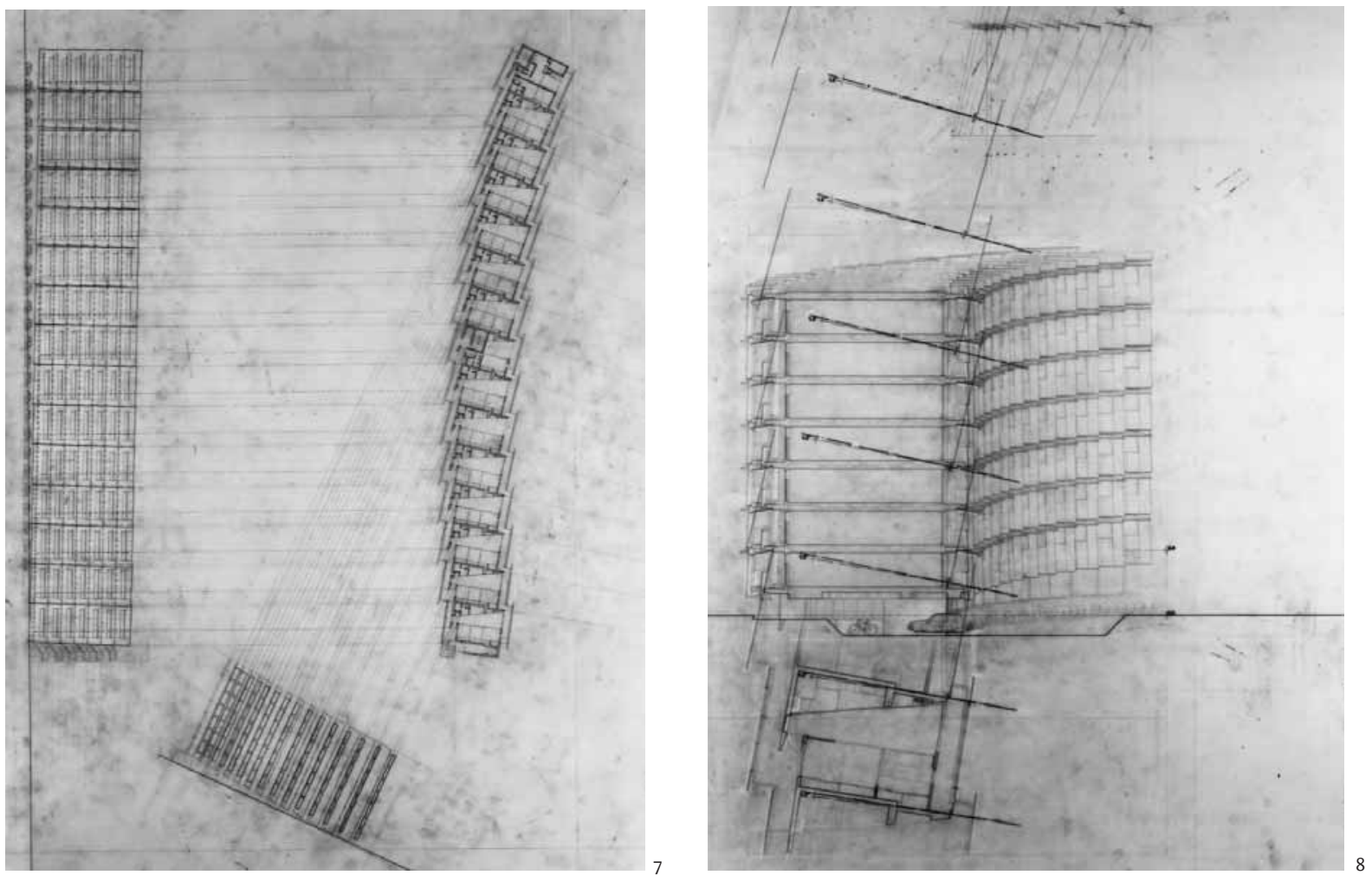

economic practicalities of the twenty-first. All practices that have employed drawing as an entrée to the profession's headiest heights have gone through this conversion at some point. Daniel Libeskind famously did it post-Jewish Museum, when legendary self-directed projects like Micromegas (1978) and Chamber Works (1983) ultimately gave way to verbal and rhetorical flourishes like those which landed him the albatross at the World Trade Center site. Bernard Tschumi, whose drawings for Parc de la Villette in Paris almost single-handedly defined draughtsmanship for a generation, and Peter Wilson, with his infamous 'bridgebuildings' and 'shipshapes', have both become thinking men's jobbing architects. Peter Eisenman has busied himself in theoretical, or what he likes to see as 'critical', dogma resistant to consumer society. Even John Hejduk, Raimund Abraham and Lebbeus Woods might have gone this route if they had had the appropriate opportunities to abandon academe. It is part of the Cooper Union way that Hejduk immortalised in Education of an Architect (1988) but whose antecedents are centuries old.

Diller Scofidio + Renfro are hyper-conscious of the transition and its effects. It is one of the reasons for the seemingly apologetic overtones that accompany any visit to their new corporate set-up in a Chelsea building precariously poised on Manhattan's westernmost edge. Even the office's archive is like the backroom of a law office. In 2006 they finally set sail from the island life. However, not only did the physical separation break the umbilical chord with Cooper Union, it finished their pencil and pen period - but not their approach, which further distinguishes them from Mayne and Morphosis who sometime earlier abandoned historiography (and Michael Rotondi) for the digital highway. It also might explain why they hastily went from commissioning a studio photographer, à la Michael Moran, to a documentary one in Iwan Baan.

\section{The plight of the building}

Recently, I was introduced to Baan, this young Dutch photographer, who supplied some photographs for an essay that I published on Rem Koolhaas. We talked in Amsterdam for a couple of days about working on 

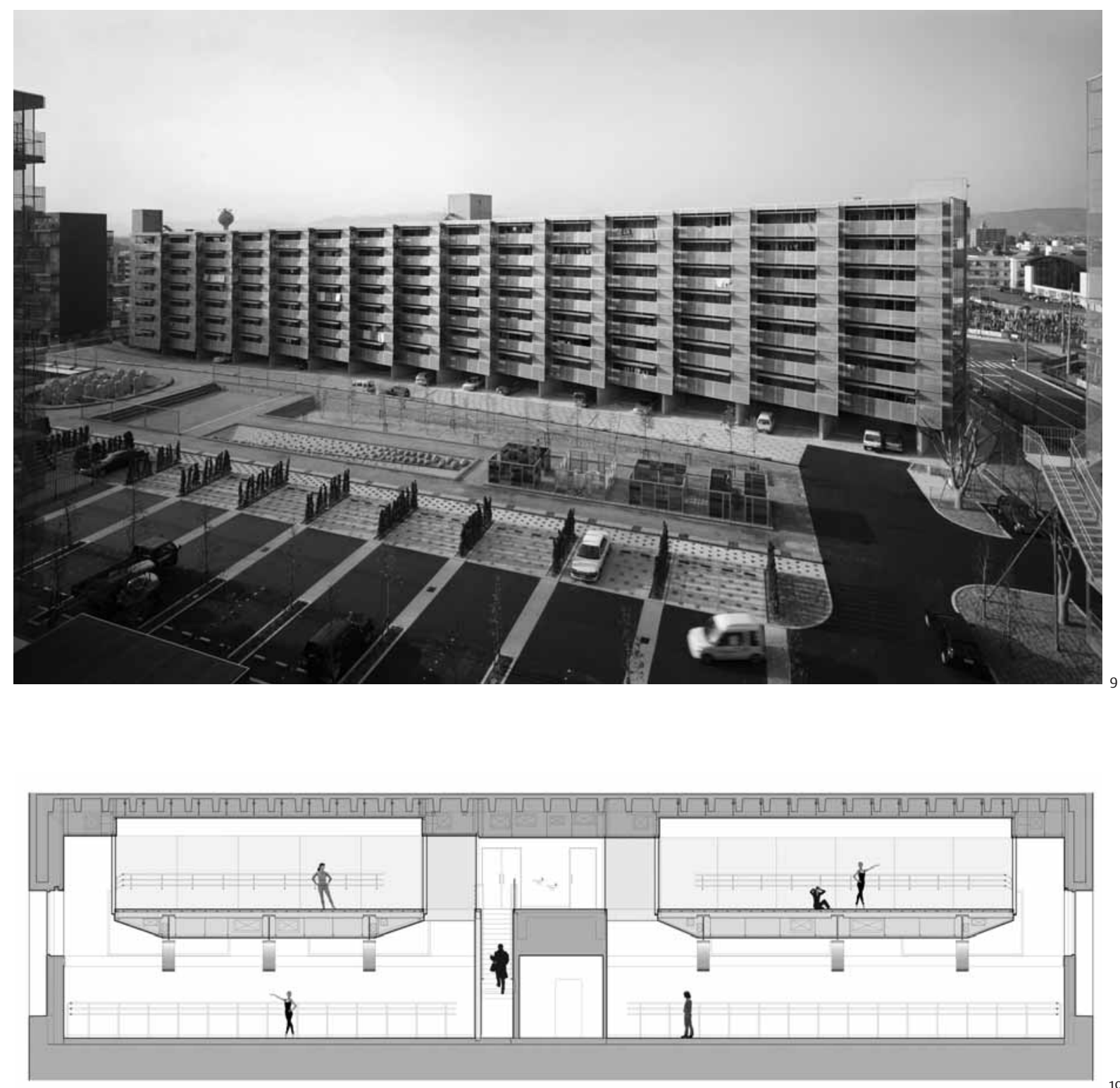

a project and he showed me some pictures that he had just taken of the School of American Ballet and the Institute of Contemporary Art. When I considered the static, macho-tectonic shots of Moran that desperately will the premature Slither Building in Gifu, Japan into reality for a Western audience alongside Baan's sumptuous, idiosyncratic shots, it brought into focus the conversion that had taken place with Diller + Scofidio (and now Renfro) and how the balance of power had shifted in their practice [9]. Like Lady Diana famously remarked 'there were three of us in this marriage'. That has had a visible effect.

What I mean is that Moran's brand of architectural evidence is surplus to the practice. Diller + Scofidio have a few buildings to photograph - Baan has been back to the SAB and ICA no fewer than three times and with Renfro on board they are increasingly involved in the time-consuming and labour intensive practice of trying to build. Baan's work reengages these two projects in all the facets of architectural representation that their drawings have abandoned. However, this also highlights the plight of the building in Diller + Scofidio's work. It has always been stuck-in-the-middle. In the early days, Diller + Scofidio's drawings signalled an artistic and intellectual temperament that generated an extensive cult and media following, in North America at least, and that proclaimed the central role of drawing in the development of an architectural project. More recently, Baan's images are called on as evidence to satisfy that demanding and, according to the Brooklyn-based thorn-in-theirside Philip Nobel, increasingly dissatisfied audience for whom the endless pre- and post-coital antics still overshadow the main event. ${ }^{5}$ Equally, in the face of an increasingly vocal cohort of NURBS nerds, packing GenerativeComponents (GC) wizardry in every Naugahyde briefcase, Baan emphasises the entirely different set of non-materialist precedents that defines DS+R's work. Although for all of Baan's recent input, the jury is still out on the value of the products of their approach in that company.

DS $+R$ barely had time to draw the School of American Ballet, except the construction documents for the contractor. The project was not won in their 

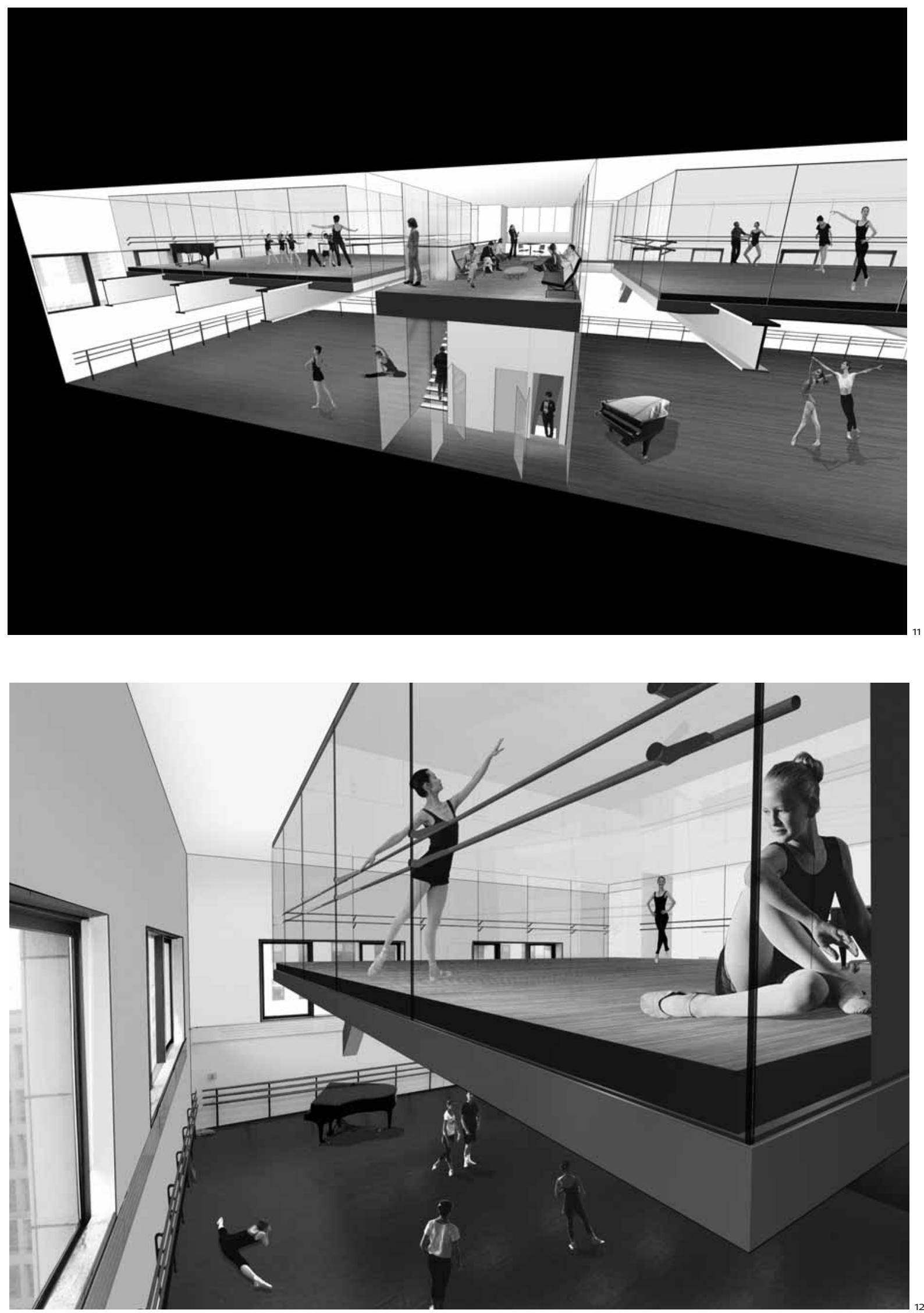

\footnotetext{
11 Overview image,

School of American

Ballet, Diller Scofidio

12 Studio perspective,

School of American

Ballet, Diller Scofidio

+ Renfro

+ Renfro
} 

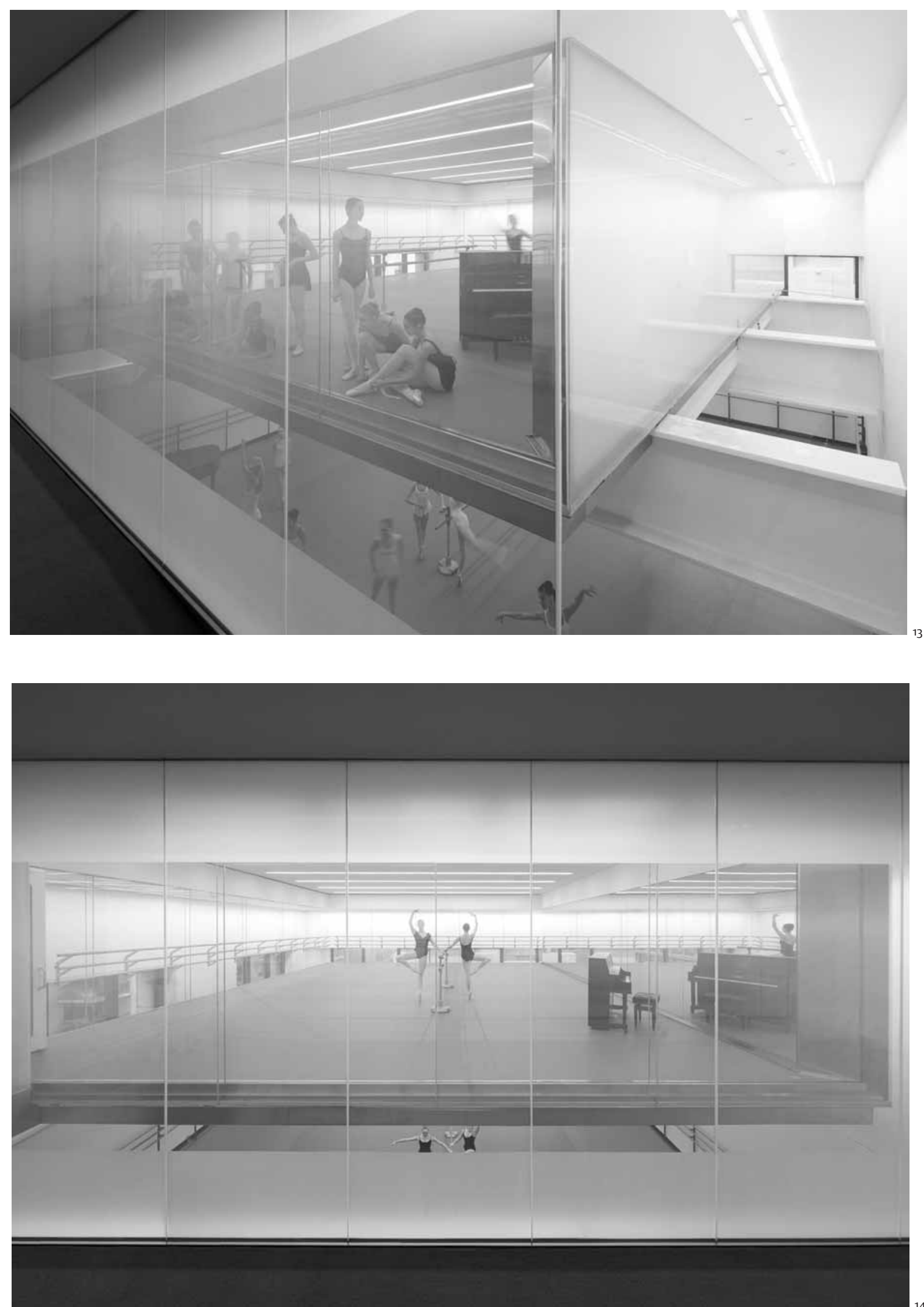

13 School of American Ballet, Iwan Baan

14 School of American Ballet, Iwan Baan

Three's a crowd Christopher Pierce 

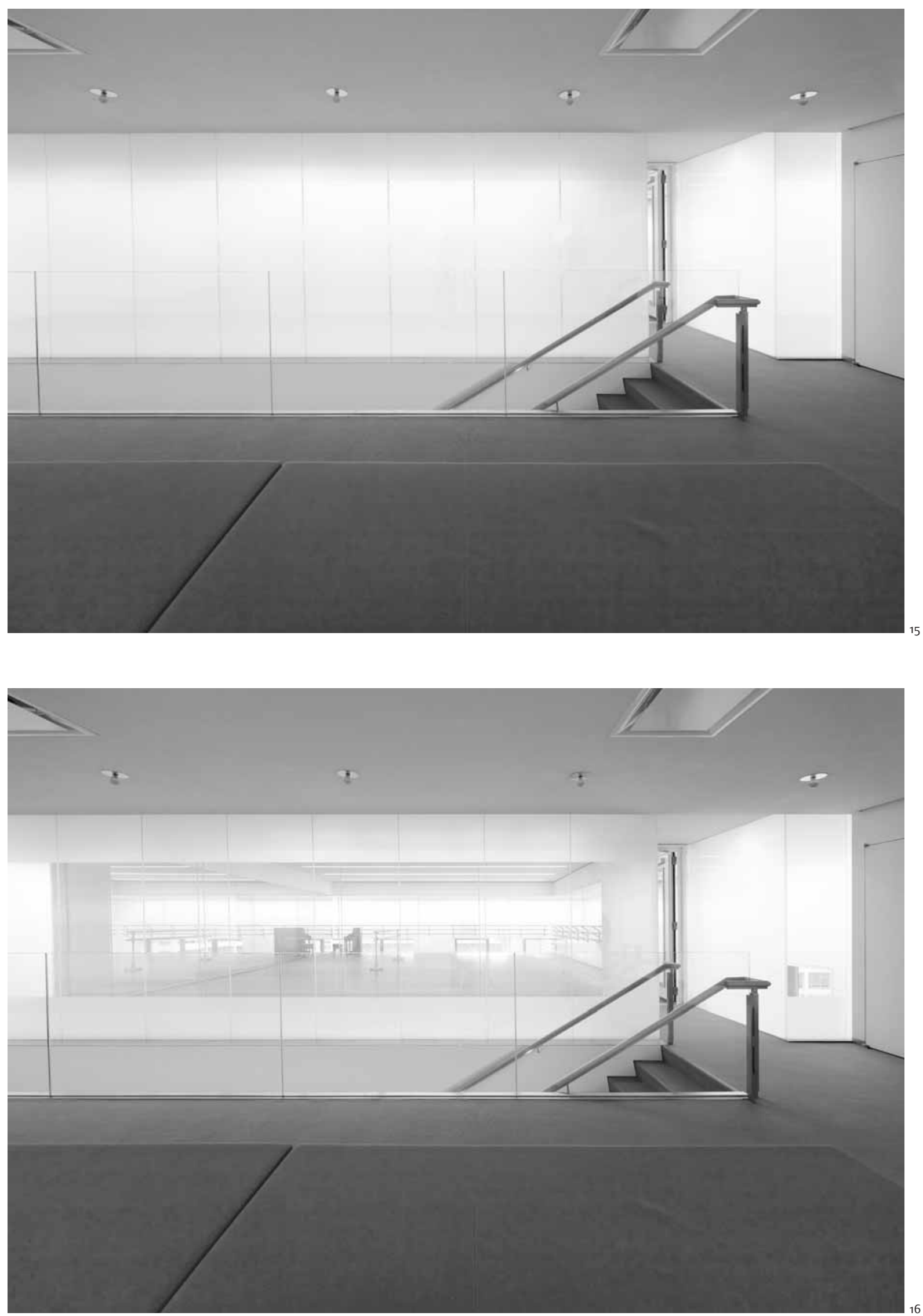

15 School of American Ballet, Iwan Baan

16 School of American Ballet, Iwan Baan
17 School of American Ballet, Iwan Baan

18 Elizabeth Diller, Ricardo Scofidio, Charles Renfro,

Robert Polidor 


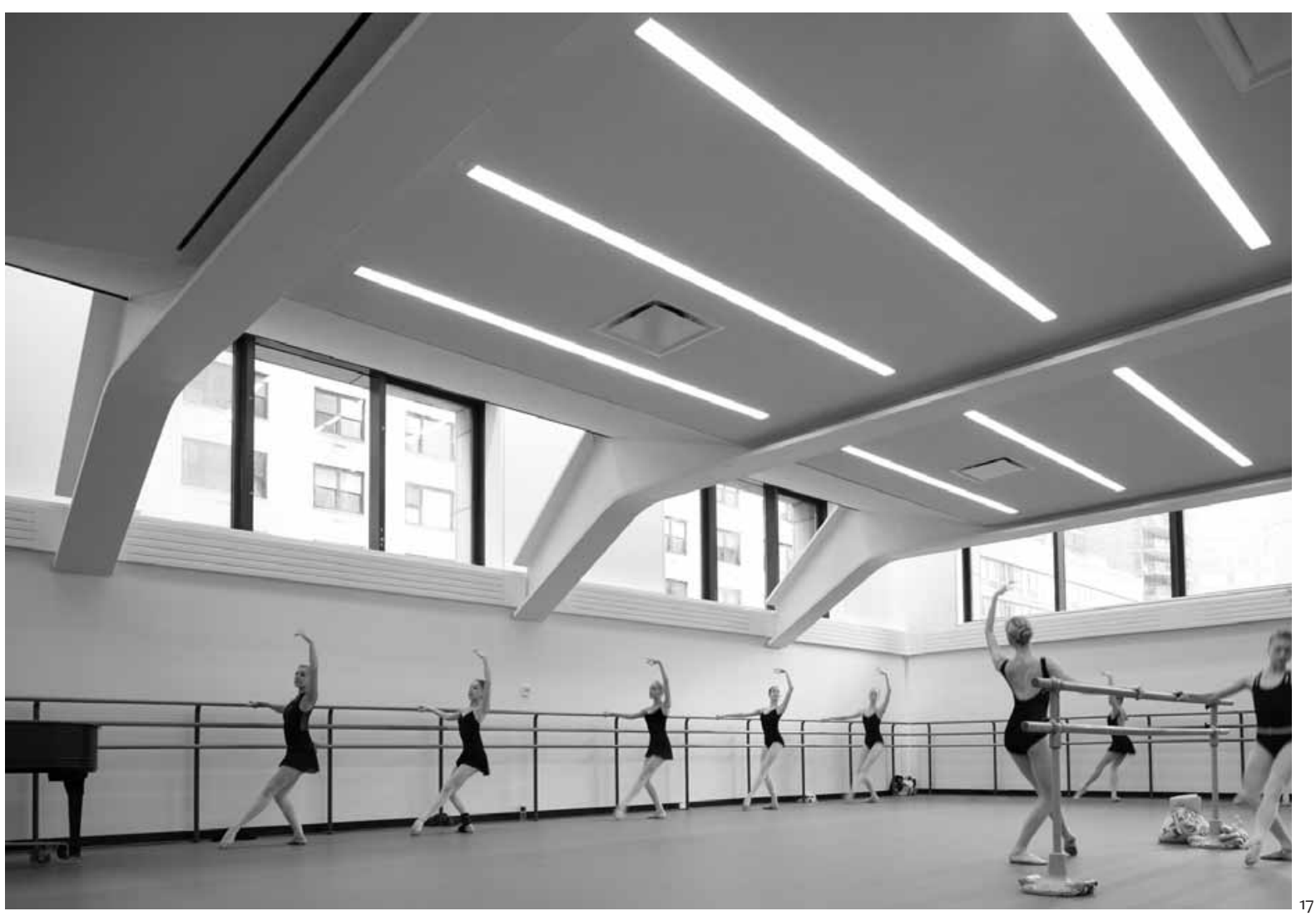

usual fashion, by competition, but by a conversation over canapés between Peter Martins, the ballet school's artistic director, and Elizabeth Diller. A single structural cum architectural manoeuvre defines the project. It was also a given. Within an existing fifth-storey building envelope, roughly 25 feet high, Diller Scofidio + Renfro suspend two volumes to create four ballet studios where there were previously only two [10]. That is the sum of the project.

The sharpness, clarity and utterly unremarkable character of the project's only two presentation images is their most immediately striking effect, although the shape and unusual angle of the 'overview image' [11] cannot help but recall the Slow House's infamous rear view mirror. Only now, nearly twenty years later, the reflected image is legible. This drawing's intent, like that of the Studio Perspective [12], is transparent and deliberately internalised. Noticeably absent are all those feint construction lines and the awkward figures that first started peopling the Blur Building. Yet these aspects are not the project's defining feature. While the commission was won and built on the back of its architectural directness, there is another important aspect of the project that Baan's photographs have rescued. His shots blur, smudge, levitate and rescale the ballet studios until this project is reclaimed and resituated within themes long present in the practice's larger oeuvre [13, 14]. When Baan records/captures the on/off of the upstairs studio's liquid crystal glass, the Slow House's windshield wiper effect is realised, previously part of the implied domain of drawing practice $[15,16]$. Baan's images permit Diller Scofidio

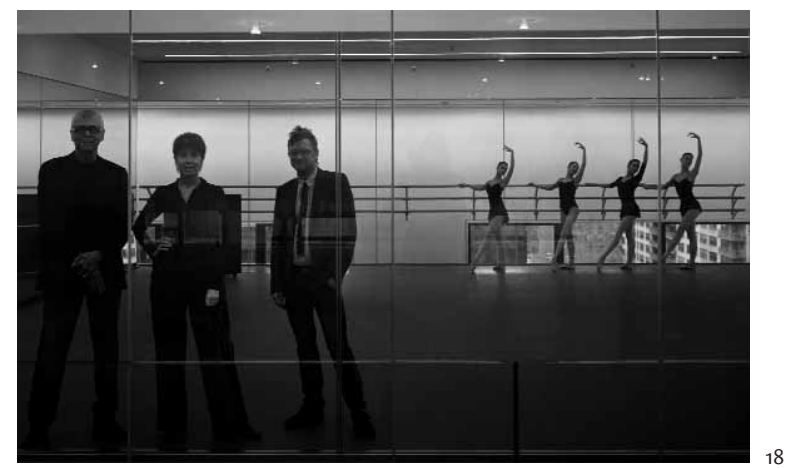

+ Renfro's construction to dissolve into the representative world, a 'cloudy' realm where their observers have become very comfortable with the practice. As Ludwig Wittgenstein famously wrote, 'you can't construct clouds'; and yet Baan reengages DS+R's built work with all of their oneiric or fantastical aspirations. ${ }^{6}$ Other Baan images invoke infinite perspectives, others dematerialise the project's boldly structural side, while yet others transform the building's modest scale into dramatic forced perspectives rarely seen since Andrea Palladio's stage sets. It is all a part of the antimaterialist tradition that pervades a particular strand of twentieth-century utopian rhetoric.

I have long admired the historiographic aspect of Diller + Scofidio's drawing practice; once potentially one of the most significant of any contemporary architectural office. Baan's photographic images build on the complex nature of the practice's early visual images, and he is managing the even more daunting task of reconciling architectural and 
representative space that for so long eluded the practice. Technology is no longer a contemporary, disorientating force, like in either the Slow House or Blur Building, but a historical construction with its antecedents rooted in European Expressionism. In fact, and perhaps understandably, Baan's coolly-lit snapshots remonstrate for this project to be considered in the contemporary and historical lineage of European architecture, which is an important audience that the practice has lacked. Arguably, he does this most successfully when Manhattan's surrounding blandness permeates the almost prescient space [17]. He pays a lot of attention to the lower level ceiling and to merging the architecture with the city, which cannot help but recall Gottfried Semper's incisive modern passages on ceilings in his nineteenth-century masterpiece Style in the Technical and Tectonic Arts; Or, Practical Aesthetics. ${ }^{\text {? }}$

The completion of the School of American Ballet coincided with a 12-page profile of the practice in The

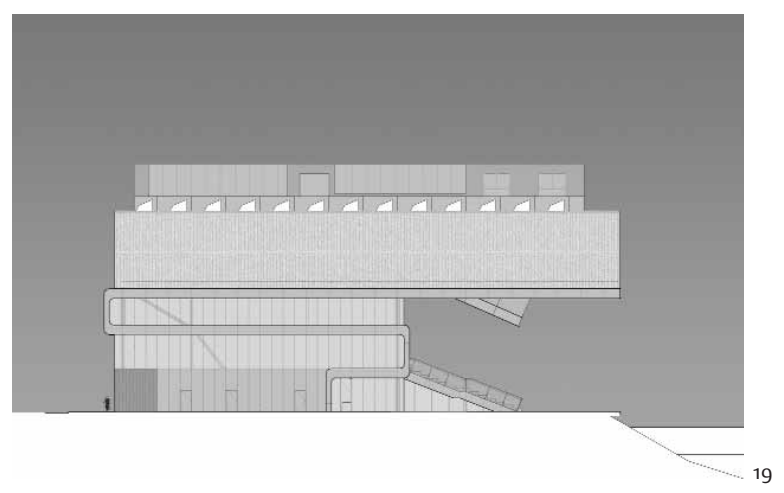

New Yorker. ${ }^{8}$ The frontispiece, shot by staff photographer Robert Polidori, shrouds the directors behind one of those expensive glass studio screens [18]. It is a long way from either the arty morphed pairing that launched D+S or Dean Kaufman's crystal clear image of the troika that recast them. All three of the images aim for the architectural canon, although much of their work evades it. Diller has been heard to remark that they are not Frank Gehry and not Rem Koolhaas, but something 'in-between'. In colonial discourse 'in-between-ness' is the empire builder's perennial fear. It is the sign of losing reason. Conditions attached to the "cultural inbetween', include vulnerability, identity-effects and placelessness. Baan's half-finished photos allow D+S $(+\mathrm{R})$ to continue their residency in an intellectual/artistic space in-between that prioritises constructing, not resolving. It is where they are best situated - although buildings that are in-between really do occupy no-place. Polidori's photo shows that the troika are an increasingly retreating/vanishing image as their building work struggles to take over. Such a manoeuvre is uncommon in the avarice of 'star-chitecture', but it might be understandable in the light of their public profile. Nevertheless, that erasure is very un-D+S-like. For the last decade, El Croquis has been the signature of arriving on the architectural stage and it is dominated by looking rough. The cult of the black and white picture is the moment of triumph and almost everyone knows what not only Elizabeth Diller + Ricardo Scofidio, but also Zaha Hadid, Enric Miralles, and Jacques Herzog and Pierre de Meuron look like in the morning.

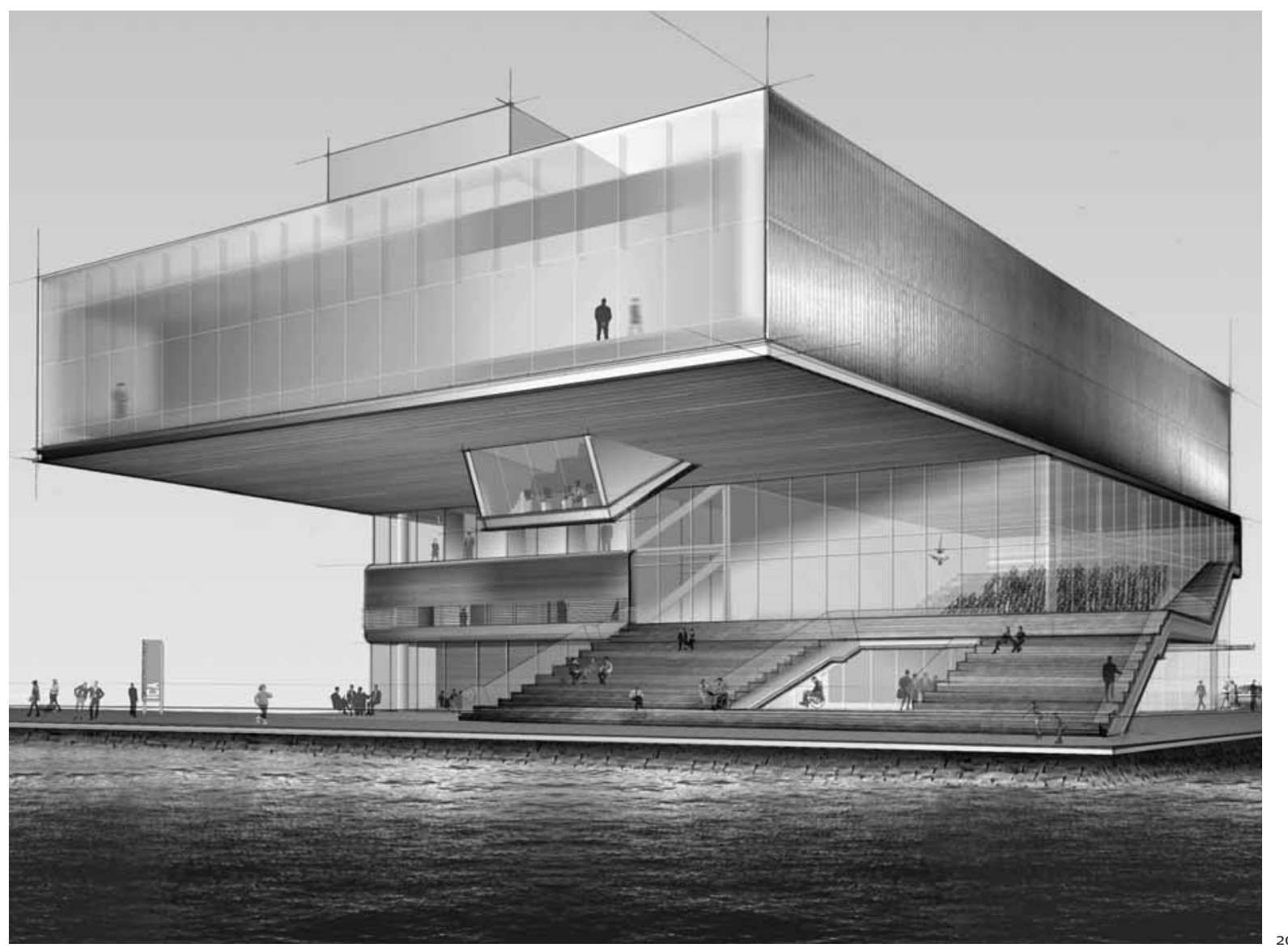




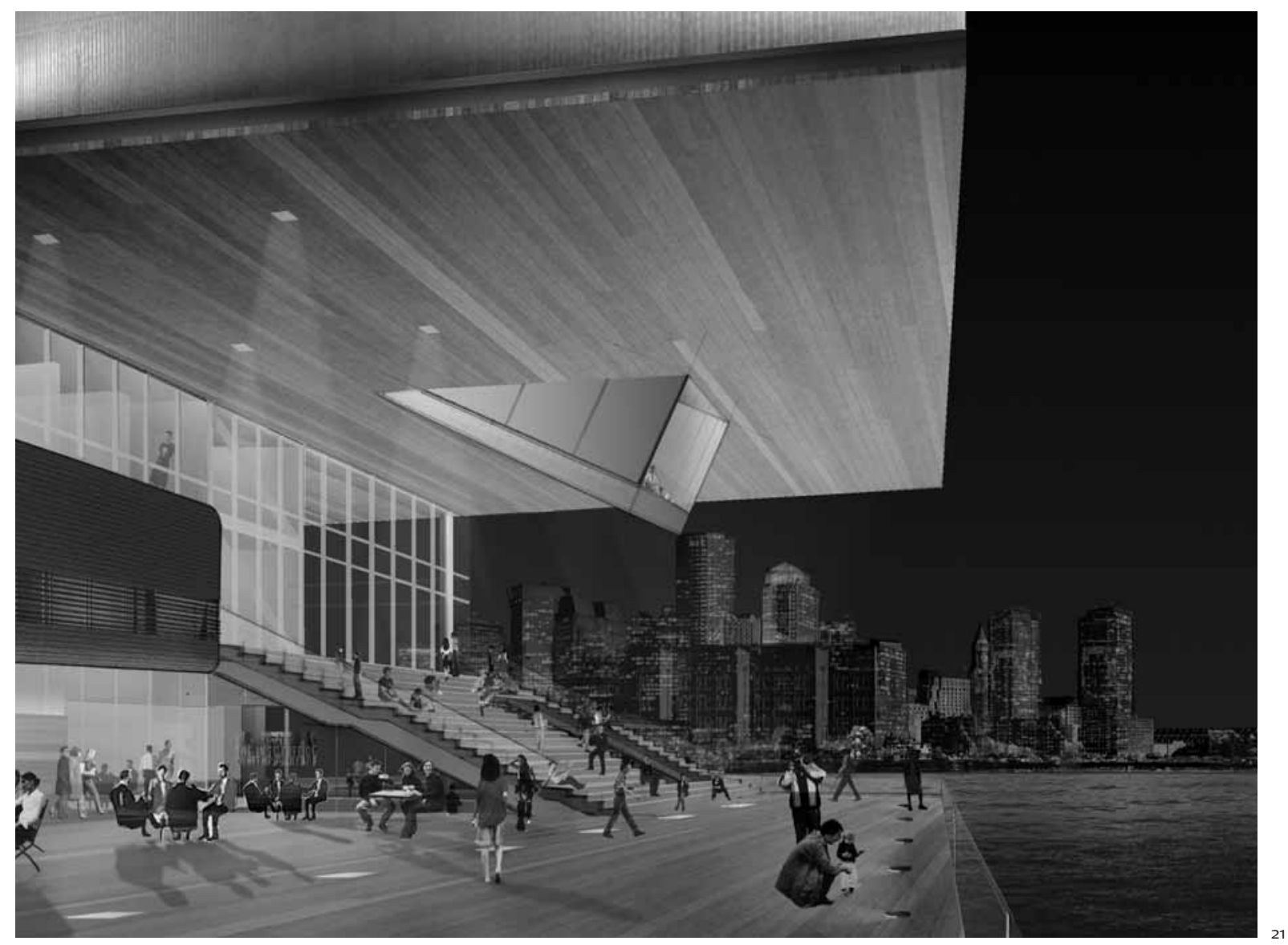

\section{Transcendent subjects}

The Institute of Contemporary Art Boston is a better indicator of Diller Scofidio + Renfro's ongoing struggle to find a way to draw/make buildings. At the ICA, there is a lot more drawing practice than at the School of American Ballet. This is a project that was won by competition, which by nature necessitates a certain indulgence and virtuosity. But the drawings and renderings are awkward architectural representations without any of the philosophical indulgence, artistic temperament, intellectual commitment or know-how of the practice's visual output in the 1980 s and ' 90 s. Not unlike the School of American Ballet, a single structural-cum-

architectural manoeuvre defines the ICA. A big glasslike box is elevated to crown the project [19]. In this case, it is a reaction to zoning regulations with a bit of showmanship thrown in at the same time.

A package of four Koolhaas-esque site diagrams, a set of half a dozen interior renderings - an unnamed taxonomy of the building's primary spaces - and a few day and night exterior views make slim pickings for the practice's former Duchampian admirers. What has hung-over are a few of Diller + Scofidio's fabled construction lines; although they are now as much a part of the artificial drawing process as the Photoshop people. It could be argued that they have become decorations or affectations begging for a raison d'être, like the building's spaces where they reappear: the Mediatheque, Long Gallery and overall exterior image [20]. These lines have been transformed into messages of handcraftedness, in other words, elements of human production that are

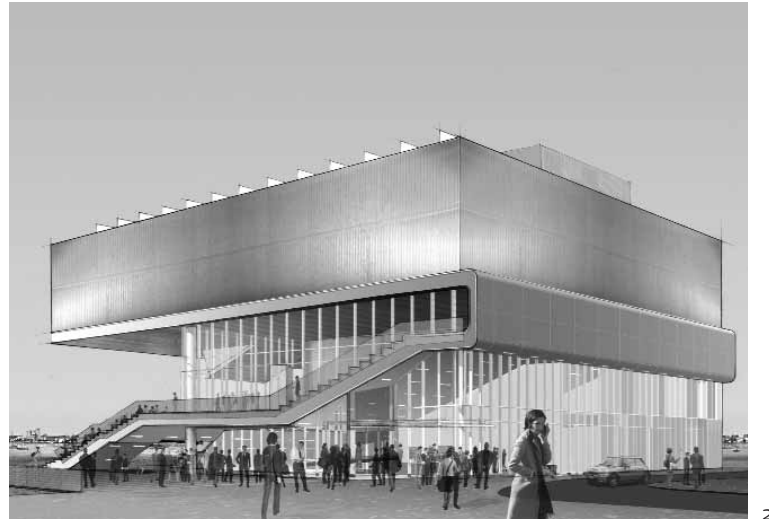

$\begin{array}{ll}\begin{array}{l}\text { 19 East elevation, } \\ \text { Institute of } \\ \text { Contemporary Art, } \\ \text { Boston, MA, Diller } \\ \text { Scofidio + Renfro }\end{array} & \begin{array}{l}21 \text { Harborwalk, } \\ \text { Institute of } \\ \text { Contemporary Art, } \\ \text { Diller Scofidio + } \\ \text { Renfro }\end{array} \\ \begin{array}{l}\text { 20 Northwest view, } \\ \text { Institute of }\end{array} & 22 \text { Southwest view, } \\ \text { Contemporary Art, } & \begin{array}{l}\text { Institute of } \\ \text { Contemporary Art, } \\ \text { Diller Scofidio + }\end{array} \\ \text { Renfro } & \begin{array}{l}\text { Diller Scofidio + } \\ \text { Renfro }\end{array}\end{array}$

at odds with their lineage - which was always previously so wonderfully other-worldly. Absent are any drawings of layers/levels, folding/unfolding, wrapping/unwrapping - which externally, on the east and west elevations, is the building's graphic and arguably only organising motif.

The detachment of the building's key spaces is cemented in the cropped Photoshop images. There is parsimony to these visualisations, not to mention a 

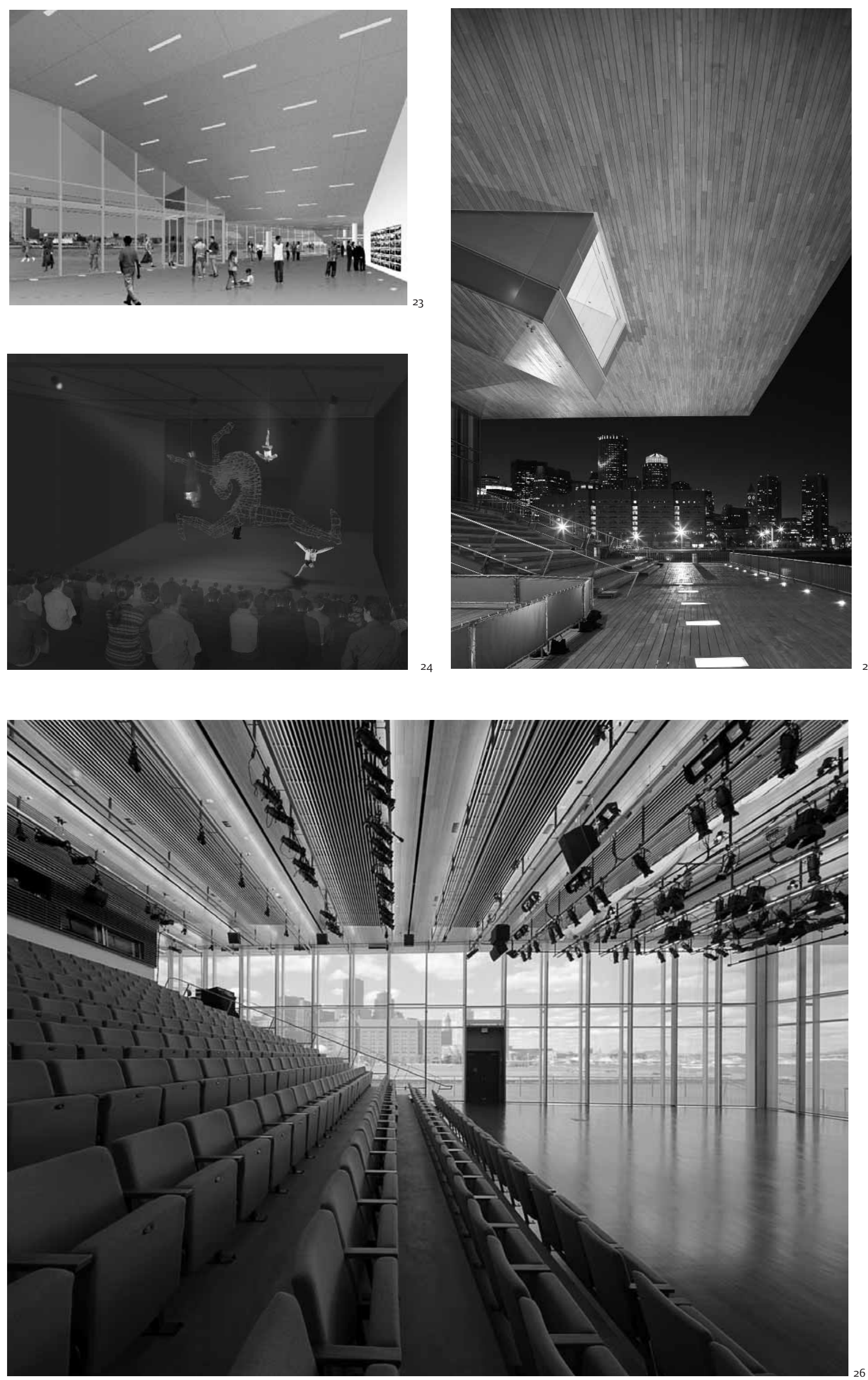

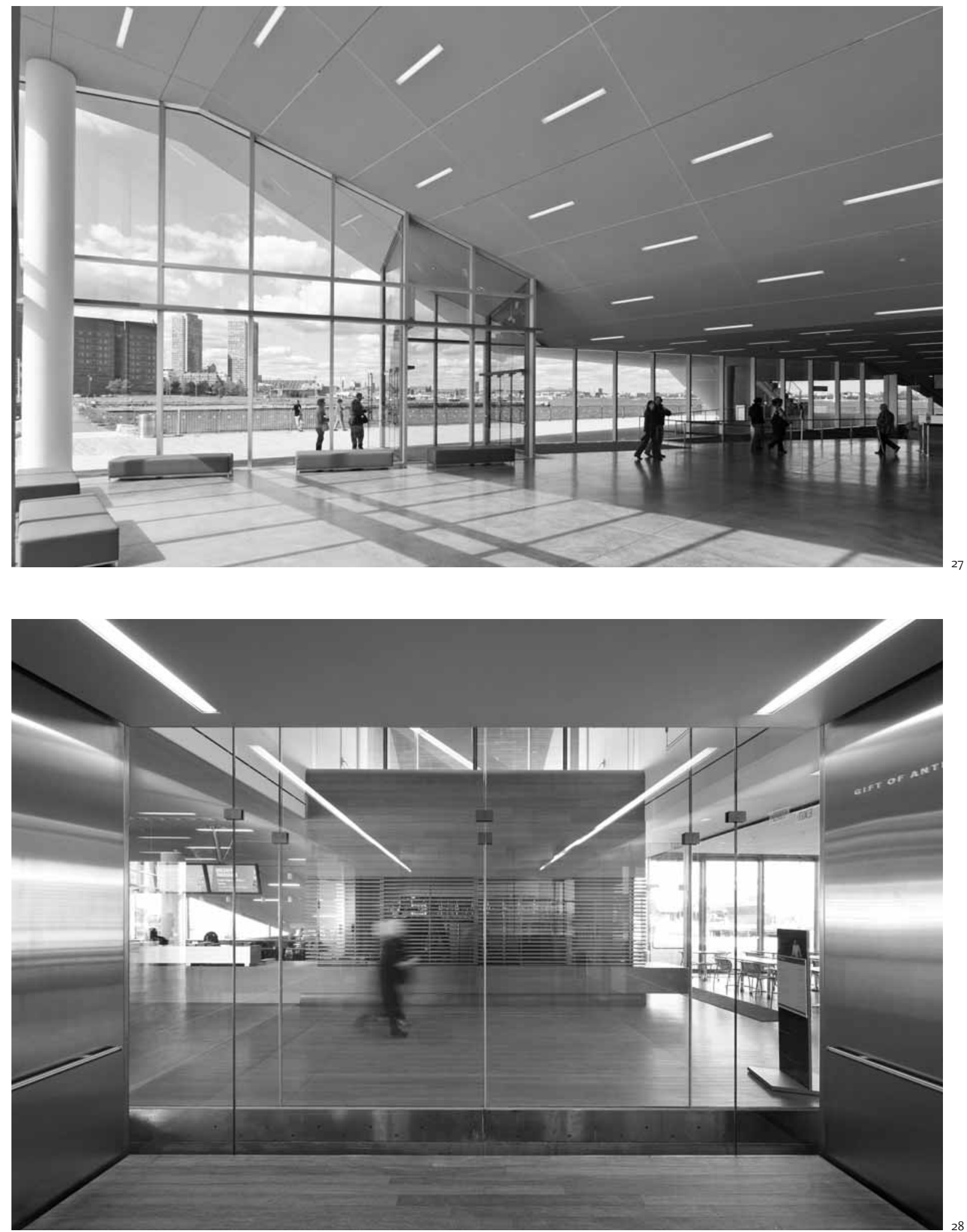

\begin{tabular}{|c|c|}
\hline $\begin{array}{l}23 \text { Lobby, Institute of } \\
\text { Contemporary } \\
\text { Art, Diller } \\
\text { Scofidio + Renfro }\end{array}$ & $\begin{array}{l}26 \text { Institute of } \\
\text { Contemporary Art, } \\
\text { Iwan Baan }\end{array}$ \\
\hline $\begin{array}{l}24 \text { Theatre, Institute } \\
\text { of Contemporary } \\
\text { Art, Diller }\end{array}$ & $\begin{array}{l}27 \text { Institute of } \\
\text { Contemporary Art, } \\
\text { Iwan Baan }\end{array}$ \\
\hline Scofidio + Renfro & $\begin{array}{l}28 \text { Institute of } \\
\text { Contemporary Art, }\end{array}$ \\
\hline $\begin{array}{l}25 \text { Institute of } \\
\text { Contemporary } \\
\text { Art, Iwan Baan }\end{array}$ & Iwan Baan \\
\hline
\end{tabular}

primitivism and socio-cultural archetype that subject architecture to a tertiary role. Their reliance on the episodic makes it hard to imagine why Diller + Scofidio failed to recall some of the techniques of their earlier work. However, the images are equally close to falling into that less successful 1980s trap of theirs and Bernard Tschumi's of imagining that architecture had something to learn from film. The Grandstand is a landscape of carnivalesque cut-outs [21]; the Entrance host to a middle-class corporate culture [22]; the Lobby a mixed scene [23]; and the 

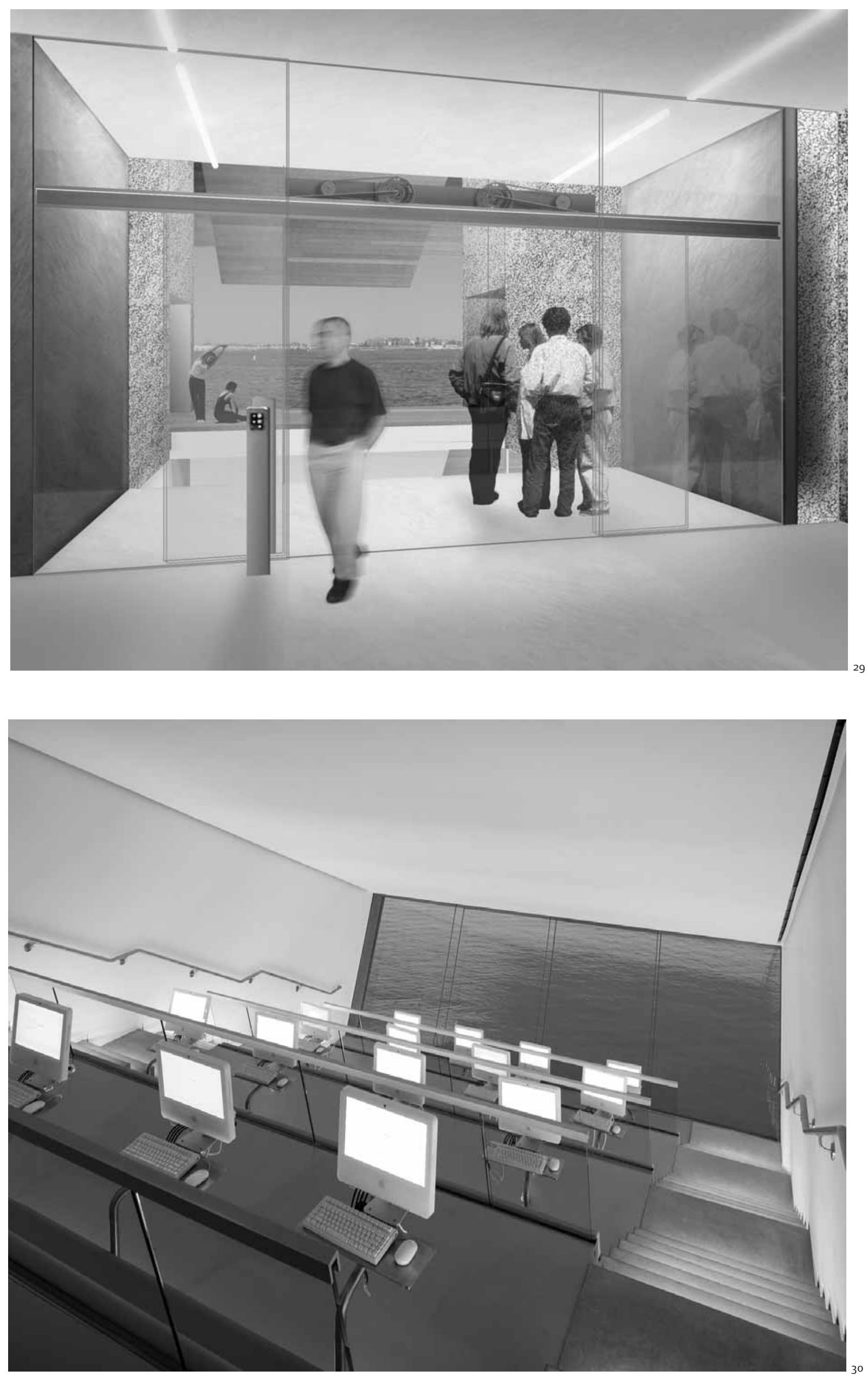
Theatre a blackout in every sense of the term [24]. Baan's photographs still subject the building to its ingrained spatial fragmentation. But he looks beyond this envelope and constructs the project's interface with the city via the ceiling [25-27]. His are not static spaces but transcendent subjects. Even in areas of the building as banal as the lift lobby, all Baan's ersatz, half-finished photos reintroduce the studio aesthetic that the practice has abandoned. Baan reminds the viewer of the referential aspects of this twentieth-century technology [28], while the studio seems satisfied to document Scofidio's

\begin{tabular}{|c|c|}
\hline $\begin{array}{l}29 \text { Elevator Landing, } \\
\text { Institute of } \\
\text { Contemporary Art, } \\
\text { Diller Scofidio + } \\
\text { Renfro }\end{array}$ & $\begin{array}{l}31 \text { Slow House, North } \\
\text { Haven Point, Long } \\
\text { Island, New York, } \\
\text { Diller + Scofidio }\end{array}$ \\
\hline $\begin{array}{l}30 \text { Institute of } \\
\text { Contemporary Art, } \\
\text { Iwan Baan }\end{array}$ & $\begin{array}{l}32 \text { Gallery, Institute } \\
\text { of Contemporary } \\
\text { Art, Diller Scofidio } \\
\text { Renfro }\end{array}$ \\
\hline
\end{tabular}

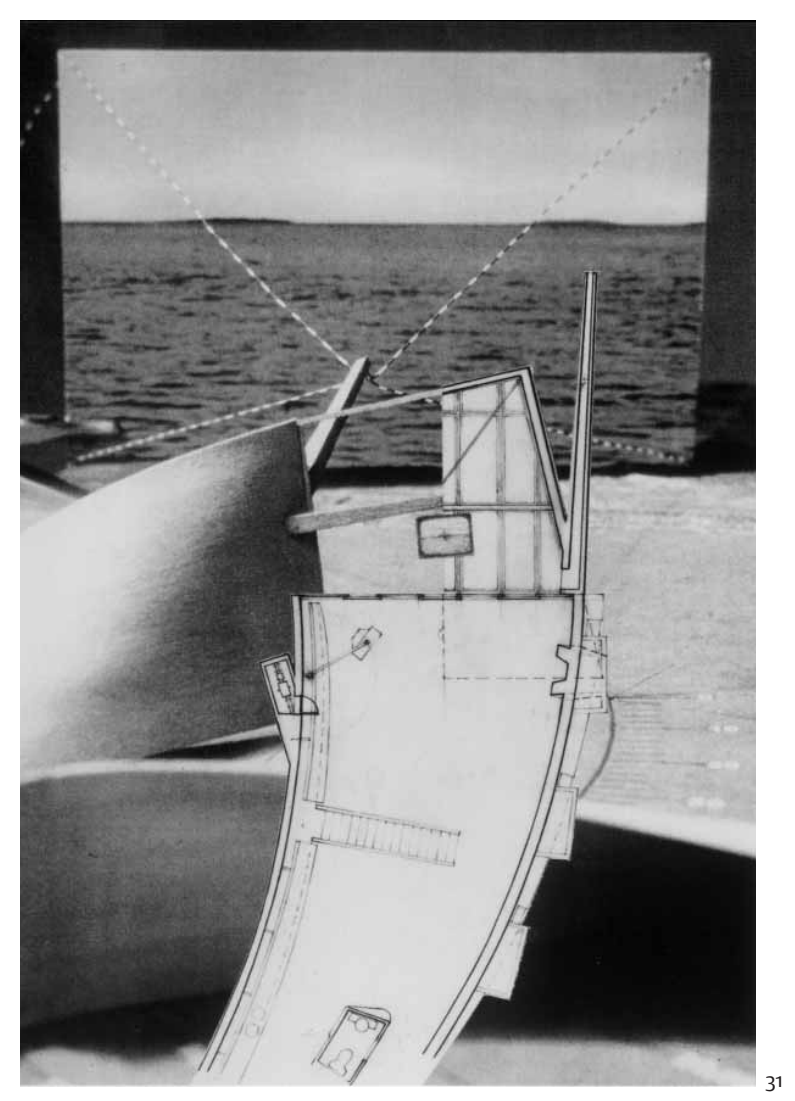

hastening departure [29]. Baan spends a lot of time in the lift lobbies giving the project a vertical aspect that its architects forgot. There is no denying the Mediatheque's ethereal charm. Baan supremely illuminates it [30]. It was also better drawn in the Slow House, from where it is clearly derived [31].

There is only one drawing of the ICA that merits consideration, a sectional perspective [32]. Let's be honest, $\mathrm{DS}+\mathrm{R}$ are never going to follow SANAA in only producing models and technical drawings. However, the level of detail, of small-scale instrumentation, that they put into the Mediatheque seat, which they somehow missed in the lift, and which is another hallmark of Diller + Scofidio's arts and installation practice, should function at the scale of the whole project. That is the raw direction that this drawing starts to develop, although Baan gives much more of a clue in the lift and ceilings. Where past drawings established an intellectual terrain, their current representations try too hard to establish an architectural one. Diller Scofidio + Renfro could have learned at the School of American Ballet that they can make a building (or at least part of one) that works. Baan can seemingly do the rest. So why are they suddenly making it so hard to discover the discourse?

\section{From drawing to photography}

Throughout the 1990s, architecture aficionados became accustomed to Diller + Scofidio being defined by drawing. Now their milieu is photography. They have skipped out that whole beat of building sometime in the middle. Since its invention, architectural photography has satisfied itself as a source of clarification and hyperrealism. There is no more iconic shot than Julius Shulman's 1960 photograph of Peter Koenig's Case Study House \#22. It has a dream-like clarity. In resolving this contemporary architectural tale, Baan is reducing, not heightening the effect. Not only are DS $+R$ interrogating the product of architecture, but Baan is almost accidentally reinventing architectural photography. Among all of the conceit and pre-planning that is a part of contemporary architectural practice, they have come upon something by accident and that is also just how Baan was first hired. So it is Scofidio again, and his reincarnation in Baan who is behind this, not the boisterous and PR-dominated side of the practice.

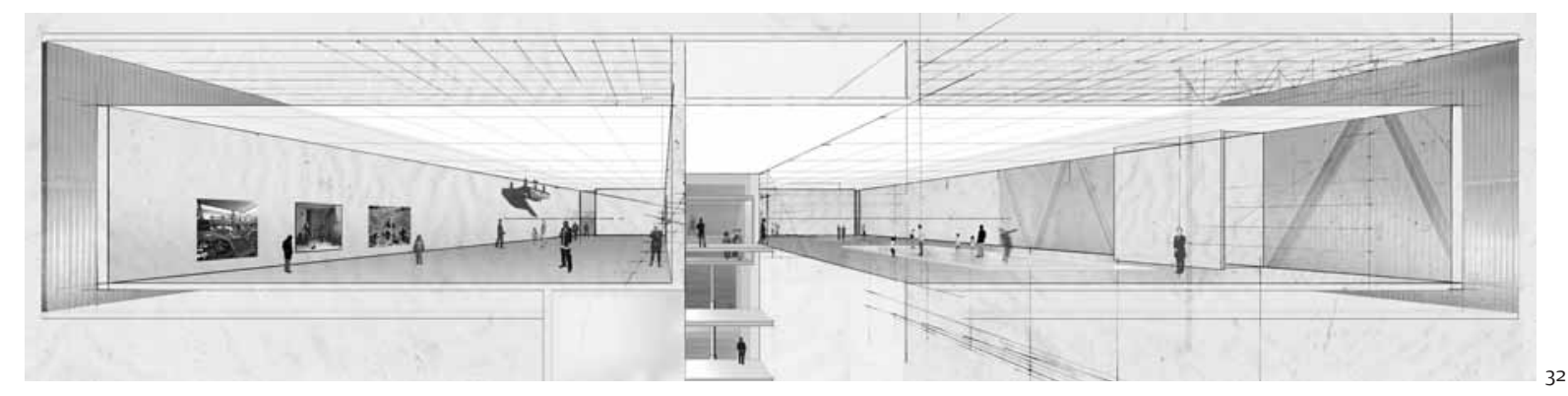




\section{Notes}

1. There is a legendary lecture at the Architectural Association, 'The Rotary Notary and His Hot Plate' transcribed in Elizabeth Diller and Ricardo Scofidio, Flesh: Architectural Probes (New York: Princeton Architectural Press, 1994), pp. 103-134.

2. Book review of Scanning: The Aberrant Architectures of Diller + Scofidio (New York: Harry N. Abrams, Inc., 2003) in The Art Book: Issues, News and Reviews, 11.1 (January 2004), 56-57.

3. Aaron Betsky, K. Michael Hays et al., Scanning: The Aberrant Architectures of Diller + Scofidio (New York: Whitney Museum of American Art, 2003).

4. Elizabeth Diller and Ricardo Scofidio, Flesh: Architectural Probes

5. See Philip Nobel, 'Die Another Day', Metropolis Magazine (May 2007) <http://www.metropolismag.com/c da/story.php?artid=2681>
6. Ludwig Wittgenstein, Culture and Value, rev. ed., ed. by G. H. von Wright, trans by P. Winch (Oxford: Blackwell, 1988), p. 48

7. Gottfried Semper, Style in the Technical and Tectonic Arts; or Practical Aesthetics, trans by Harry Francis Mallgrave and Michael Robinson (Los Angeles: Getty Publications, 2004), pp. 146-153.

8. Justin Davidson, 'The Illusionists: How Diller Scofidio + Renfro is transforming New York', The New Yorker, 83.12 (14 May 2007), 126-137.

\section{Illustration credits}

arq gratefully acknowledges:

Iwan Baan, 13-17, 25-28, 30

Diller + Scofidio, 1, 2, 5-8,

Diller Scofidio + Renfro, 10-12, 19-24, 29, 31, 32

Michael Moran, 9

Morphosis, 3,

Robert Polidori, 18

\section{Acknowledgements}

Christopher Pierce thanks Iwan Baan; Michael Hundsnurscher, Flavio Stigliano and Eamon Tobin at DS+R; Thomas Schoff at the SAB; Brigham Fay at the ICA Boston; Lauren Rosenbloom at Morphosis; Hugh Campbell and Douglas Smith at University College Dublin; Michael Moran, Robert Polidori, Anthony Vidler and Tom Weaver.

\section{Biography}

Christopher Pierce is a Principal Lecturer at the University of Brighton and Intermediate Unit Master at the Architectural Association (AA) in London.

\section{Author's address}

Dr. Christopher Pierce Faculty of Arts and Architecture University of Brighton, Grand Parade Brighton, BN2 oJY UK 